\title{
Juridical Analysis of Marine Pollution by Tankers in Riau Archipelago Waters: A Case Study at the Environmental Service, Riau Islands
}

\author{
Danny Priabudi ${ }^{1}$; Laily Washliati ${ }^{2}$ Idham $^{3}$ \\ ${ }^{1-3}$ Faculty of Law, Universitas Batam, Indonesia \\ Corresponding Author: Idham
}

\section{ABSTRACT}

Indonesia is a country rich in resources, especially natural resources, but population growth is not proportional to the availability of natural resources. Malthus predicts that population progress to increase in quantity is greater than the ability of natural resources to provide human food needs. The environment cannot support an infinite amount of life if the earth is no longer able to support the explosion in the number of humans and their activities. Indonesia is a country known as a maritime country, which means it is mostly water and consists of islands. Sea transportation is very important to connect the islands scattered throughout Indonesia. The development of environmental law is urgently needed which cannot be separated from the world movement to give greater attention to the environment. In marine pursuits, such as fishing, excessive fish species using trawlers can lead to extinction. Pollution of the marine environment is a threat to human life, animals, and plants. Increased use of the sea can have a direct impact on the marine environment and the biota in it. The Environment Agency is one of the institutions that play a role in handling the impact of marine environmental pollution in the region. The purpose of this research is to find out the Legal Regulation of Marine Pollution by Tanker Ships in the Riau Archipelago Waters. The aim is to find out what factors are being carried out in handling marine pollution by tankers in the waters, especially in the Riau Islands Environmental Service. It is hoped that this will lead to a better understanding of the environmental impact of marine pollution in the region. The Riau Islands Environment Agency
\end{abstract}

is responsible for compensation for losses caused by pollution of the marine environment by persons or legal entities within its jurisdiction. Each country must cooperate in implementing international law which regulates the responsibility and obligation to compensate for losses due to pollution. The International Maritime Organization is a leading organization in producing various regulations on marine pollution, especially those caused by oil.

Keywords: Marine Pollution, Tanker Ships, Riau Islands

\section{INTRODUCTION}

Indonesia is a country rich in resources, especially natural resources. This is one way of using capital to carry out development that aims to improve the welfare of the people. However, natural resources are limited, while population growth is not proportional to the availability of natural resources.

Malthus, with his postulates, predicts that the progress of the population will increase in quantity greater than the ability of natural resources to provide human food needs (Erwin, 2012). Therefore, the use of natural resources must pay attention to their availability in the future. For this reason, wisdom and accuracy, and prudence are needed in managing natural resources so that they can be utilized properly to achieve the aspired goals.

The declining quality of the environment, coupled with the depletion of natural resources and the emergence of 
various environmental problems, have made people aware of the importance of environmental support and the role of natural resources in life in the universe. The environment cannot support an infinite number of lives. If the earth is no longer able to support the explosion in the number of humans and their activities, humans will experience various difficulties. The growth of the earth's population absolutely must be controlled and human activities must also pay attention to environmental sustainability.

Environmental preservation means that the environment must be maintained as it is. Meanwhile, the environment is actually used in the framework of development. This means that the environment is undergoing a process of change. In the process of this change, it is necessary to maintain the environment so that it is still able to support a normal life.

The country of Indonesia is known as a maritime country whose most of its territory is water, as well as islands located in the positions of world trade routes. Therefore, the role of sea transportation is very important. Besides being a liaison and means of transportation, it also plays a role in the resilience of a country. Ship transportation is a commercial shipping company engaged in the provision of sea transportation services to promote domestic and foreign trade. One example is the delivery of goods, both raw and finished goods, to other countries which will increase the country's foreign exchange income (Erwin, 2012).

Basically, economic development endeavored to increase the prosperity and welfare of the community within a country. The progress of economic development is characterized by high growth in various existing economic sectors, such as the industrial sector, which produces goods and services, as well as the trade sector, which distributes them. With the higher economic growth, these sectors require various supporting facilities and infrastructure, so that the sub-sectors in the economy can interact properly in the sense that the goods and services produced by the industrial sector are immediately distributed to consumers. Sea transportation facilities and infrastructure are ports, ships, and officers (Government Agencies) appointed as representatives or known as agencies. Most sea transportation facilities and infrastructure allow transportation business activities to run well. A ship is a connecting tool at sea that is known by the public in general.

Indonesia is a country known as a maritime country, most of which is water and consists of islands. The Unitary State of the Republic of Indonesia is an archipelagic state characterized by an archipelago united by very wide territorial waters with boundaries, rights, and sovereignty stipulated by law. Indonesian waters are the Indonesian territorial seas and archipelagic waters, as well as their deep waters. This statement clearly shows that most of Indonesia's territory is the sea and islands which require sea transportation modes to connect the islands and support economic growth (Erwin, 2012).

Therefore, sea transportation is very important to connect the islands scattered throughout Indonesia. One of the means of sea transportation is sea transportation in the form of ships. A ship is a vehicle for transporting passengers and goods at sea. Ship transportation is a shipping company engaged in the provision of sea transportation services. Sea transportation services include passenger and cargo transportation services.

Indonesia's maritime area includes tens of thousands of islands with a very wide territorial sea. Indonesia is the largest archipelagic country in the world, with the world's largest territorial sea and 95,108 km of coastline, the fifth-longest in the world. Indonesian marine waters have a strategic geographical position as a commercial and military route (Windari, 2011). Shipping operators must follow the development of science and technology to realize the development of the national and 
international strategic environment that still expresses the safety and security of shipping for the sake of the national interest.

Sea transportation is one of the national transportation systems whose potential and role must be developed to realize an effective and efficient transportation system, as well as to help create a stable and dynamic national distribution pattern. The role of sea transportation needs to be regulated by the state so that the implementation of sea transportation activities can be carried out in an orderly manner and protect the interests of all parties involved in it.

Shipping safety and security is a condition of the fulfillment of safety and security requirements concerning transportation in waters, ports, and the maritime environment. Water transportation is a unified system of shipping that has passengers or goods using ships.

The role of shipping companies is very important for the world of shipping in Indonesia. PT. Pelayaran Nasional Indonesia (Persero) is a State-Owned Enterprise that is engaged in shipping. PT. Pelayaran Nasional Indonesia (Persero) is a national shipping company that provides sea transportation services, including passenger and cargo transportation services between islands. To implement government policies, PT Pelayaran Nasional Indonesia (Persero) Branch offices were opened in several regions in Indonesia, including in Semarang. The ship is operated by PT. Pelayaran Nasional Indonesia (Persero) Semarang branch is a ship for passenger transportation, or often called a passenger ship, and a Ro-Ro (Roll on-Roll off) type ship, namely passenger ships, and ships that can load vehicles that walk into the ship, for example, loading cars and trucks.

A ship is a water vehicle of a certain shape and type that is driven by wind power, mechanical power, and other energy. Ships are used as a mode of sea transportation to support economic growth, regional development, and to help create a dynamic national distribution pattern. To achieve this, all ships should be able to sail safely. Given the important and strategic role of sea transportation, its existence is controlled by the state whose guidance is carried out by the government as mandated by Law 17 of 2008 concerning shipping.

Based on this, the three main pillars are then implemented into the law on shipping and their implementing regulations such as Government Regulations (PP) and Ministerial Decrees. To be more strict in its implementation, sanctions in the form of fines of up to hundreds of millions of rupiah and/or criminal imprisonment are included in Law Number 17 of 2008 concerning Shipping.

Law Number 17 of 2008 concerning Shipping is a public law, namely, the law governing the public interest is made to accommodate all interests related to sea transportation, and according to the explanation of Law Number 17 of 2008 concerning Shipping, it is intended that the operation of shipping as a system can provide maximum benefit to all the people, nation and state, fostering and developing a maritime spirit by prioritizing the public interest and environmental sustainability, coordination between the center and the regions as well as state defense and security.

According to Law Number 17 of 2008 concerning shipping, several unlawful acts do not only provide civil sanctions or administrative sanctions but also criminal sanctions, so it can be estimated that, according to the legislators, only criminal sanctions can effectively protect social values the basis in question.

Law Number 17 of 2008 concerning shipping, which contains acts subject to criminal sanctions, is acts that violate provisions that are not sufficiently disciplined only by using administrative sanctions or civil sanctions. Administrative sanctions or civil sanctions are not effective enough to have an effect and prevent others from committing the same act.

Criminal provisions in the shipping sector at least provide a guarantee for the implementation of safe and comfortable sea 
transportation, to encourage the growth of sea transportation which in turn supports economic growth so that it does not become an obstacle to the implementation of sea transportation or shipping in the context of serving the mobility of people, goods and services. linking inter-island economic activities and international relations.

In terms of ship shipping, there is a great need for the development of environmental law which cannot be separated from the worldwide movement to give greater attention to the environment, given the fact that the environment has become a problem that needs to be tackled together for the sake of survival in this world (Strake, 2011). Natural resources both on land and in the sea must be guaranteed sustainability, among others while maintaining the marine environment. In conditions that relate to the nature of the sea, as well as management systems in seeking existing natural resources. The growing awareness that is created will help coordinate the sea or meet the needs of the sea. This is a step towards realizing the preservation of the marine environment as well as the unlimited resources contained in the sea. In pursuing the sea, for example, fishing, excessive types of fish using tiger trawls are very dangerous and can cause extinction that cannot be felt in the short term (Joko, 2012).

Pollution of the marine environment is getting a lot of attention from the world today, whether it is nationally, regionally, or internationally due to its impact on environmental sustainability and the benefits of natural resources in the sea being disrupted both for the national interest of coastal countries and mankind as a whole.

Symptoms of pollution of the marine environment in the last decade have received a lot of attention from various parties. As seen in the discussions through seminars and symposiums held at the national, regional, and international levels, all of these concerns are discussed and studied marine environmental issues, thereby sharpening understanding and raising awareness about marine environmental issues.

This understanding and awareness generally imply that the problem of marine environmental pollution poses a threat to the life of both human, animal (fauna), and plant (flora) life. These three types of life that fill the environment or "biosphere" above the globe are threatened for their survival and sustainability because they are exposed to toxins that cause destruction. Therefore, the currents and winds of polluted seawater are spread everywhere evenly and affect the marine environment.

It is common knowledge that the sea has several functions, including a vital one for the life of the nation. Increasing the use of the sea for the life of a nation based on its functions can have a direct effect on the marine environment and the biota in it. In the beginning, the use of the sea was not a problem for human life. This is because the sea is still able to clean itself without changing and affecting the nature and function of the sea as before. However, recently, due to the increasing use of the sea, the entry of new substances into the sea plus the existing substances causes the sea to no longer be able to clean itself so that the sea becomes dirty, which sometimes reaches the level of changes in the function of the sea. At that time, the sea will become a source of problems that threaten human life, so new problems will arise for human life, namely marine pollution.

The formulation of the problem is an important part of legal research to produce research that has a clear and targeted target. Based on the background described above, the research problem can be formulated as follows.

(1) What is the law on marine pollution by tankers in the waters of the Riau Archipelago?

(2) How is the implementation of handling marine pollution by tankers in the waters of the Riau Archipelago?

(3) What are the obstacles and efforts being made to deal with marine pollution caused by tanker ships in the Riau 
Archipelago, particularly in the Riau Islands Environmental Service?

The objectives to be achieved in this research are as follows.

(1) Determine the legal framework for marine pollution caused by tankers in the waters of the Riau Archipelago.

(2) In order to find out the implementation of handling marine pollution by tankers in the waters of the Riau Archipelago.

(3) Determine the factors that become impediments and the efforts made in dealing with marine pollution by tanker ships in the Riau Archipelago Waters, particularly in the Riau Islands Environmental Service.

This research is expected to provide theoretical and practical benefits. Referring to the research framework, the theoretical benefit of research is to develop legal knowledge, especially in the field of handling marine pollution by tankers in Indonesian waters. Able to provide views of thought in the form of concepts or theories in the field of law regarding the Handling of Marine Pollution by Tankers in Indonesian Waters. Meanwhile, the practical benefit of research is to provide answers to the problems studied; to provide a more realistic picture of the handling of marine pollution by tankers in Indonesian waters.

\section{LITERATURE REVIEW}

The theoretical framework is a syntactically integrated set of prepositions (that is, those that follow certain rules that can be linked logically or with other basic observable data) and serves as a vehicle for predicting and explaining the observed phenomena (Molloeng, 2012).

There are three things that need to be considered in taking a closer look at the theory, namely: (1) a theory is a set of propositions consisting of constructs that have been defined broadly and with clear relationships between the elements in the set. (2) The theory explains the relationship between variables or between constructs so that a systematic view of the phenomena explained by the variables is clearly visible.
(3) The theory explains the phenomenon by specifying that one variable is related to another variable.

\section{Regulation of Marine Pollution Law in Indonesia}

Indonesia is a country that has abundant marine wealth, which is based on the vast sea area in Indonesia which is its main potential. Arrangements regarding the sovereignty and jurisdiction of states at sea are comprehensively regulated in the 1982 UNCLOS (United Nations Convention on The Law of The Sea), which recognizes the right of states to make claims over various marine zones with different legal statuses. So far, the juridical notion of territory is limited to the issue of sovereignty, while in arrangements based on the international law of the sea, it is known that there is state jurisdiction in parts of the sea that are not the territory of the state, so the discussion in this subsection cannot be separated from the problems mentioned above (Jalal, 2011). Indonesia's national interests in the sea are not only limited to marine zones which are the territory of the state but also include parts of the sea outside the territory of the state where Indonesia has sovereignty and jurisdiction for its use.

\section{Shipping Law in Indonesia}

According to Law Number 17 of 2008, Article 1 point 36, a ship is a water vehicle with a certain shape and type that is driven by wind power, mechanical power, other energy, pulled or delayed, including vehicles with dynamic support, vehicles below the water surface, as well as floating equipment and floating structures that do not move. Furthermore, in the explanation of what is meant by "ship" is: (a) A ship driven by the wind is a sailing ship. (b) Ships that are driven by mechanical power are ships that have propulsion devices, for example, motor ships, steamships, ships with solar power, and nuclear ships. (c) A ship being towed or towed is a ship that moves by using another ship's propulsion device. (d) Vehicles with dynamic carrying 
capacity are types of ships that can be operated on the surface of the water or the surface of the water by using dynamic carrying capacity caused by the speed and/or design of the ship itself, for example, jetfoil, hydrofoil, and fast boats others that meet certain criteria. (e) Vehicles under the water surface are types of ships capable of moving under the surface of the water. (f) Floating equipment and floating buildings that do not move are floating equipment and floating buildings that do not have their means of propulsion, and are placed in a certain water location and do not move at the same time. For example, floating hotels and accommodation stands (bargers) to support offshore activities and oil storage barges, as well as mobile offshore drilling units.

\section{Regulation of Marine Pollution by Tankers}

Indonesia continuously considers it necessary to implement environmental management to preserve and develop a harmonious, harmonious, and balanced environmental capability to support the implementation of sustainable development with an environmental perspective. Environmental protection and management is a systematic and integrated effort carried out to preserve environmental functions and prevent environmental pollution and/or damage which includes planning, utilization, control, maintenance, supervision, and law enforcement. In Article 6 of the Law on Environmental Protection and Management (UUPPLH), it is stated that "everyone is obliged to maintain the preservation of environmental functions and prevent and overcome pollution and environmental destruction."

Thus, in terms of protecting and maintaining the environment, it is the obligation of every citizen of the state, meaning of environmental sustainability itself includes the preservation of the aquatic or marine environment, both national seas, and international seas. The Environmental Protection and Management Law (UUPPLH) itself explicitly recognizes the absolute responsibility regime for every environmental pollution incident that occurs. The consequence that occurs when national law only recognizes absolute responsibility in cases of environmental pollution is the potential for denial of certain parties, especially those who are said to be involved in the environmental pollution that has occurred. It is true that in the general concept of international law, Indonesia has the right to exercise its jurisdiction to directly impose liability on ships that pollute the marine environment within Indonesian waters.

\section{Indonesian Maritime Law Standard Ship Registration Arrangements}

Vessel registration in Indonesia is reviewed from Article 314 of the KUHD, namely Indonesian ships whose size is at least 20.m3 gross can be registered in a Vessel Register in accordance with regulations called a separate Ordinance (Regeling van de Teboekstelling van Schepen), namely Ordonation 4 February 1993 Stb. 1933-48 jo. 1938-2. The ordinance came into force on April 1, 1983, regulating the registration of ships in the ship register, the delivery of registered ships, as well as the installation and delivery of mortgages and other property rights.

In this regulation, a ship that has been or is being built in Indonesia can be considered as an Indonesian ship until the manufacturer hands over the ship to a person who has or is currently financing the construction of the ship or for its responsibility for the voyage.

\section{Implementation of Marine Pollution Law Regulations in the Riau Archipelago}

Maritime Environment Protection is every effort to prevent and overcome pollution of the aquatic environment originating from activities related to shipping. Maritime protection is very necessary for a clear arrangement in carrying out and implementing it. Indonesia's maritime environment is very broad and almost every aspect of life in 
Indonesia is related to the waters, which is also known as the maritime environment.

Indonesia is a coastal country where if there is pollution in the marine environment, for example by pollutant substances such as oil, it will certainly cause damage that affects the surrounding marine environment. Indonesia is rich in its natural resources. Natural resources include living and non-living natural resources and natural resources that can be renewed or nonrenewable natural resources. At this time, marine pollution often occurs, which is caused by oil spills. Oil spilled in the sea will cause various damage to the sea. Prevention and control of marine pollution from ship operations as contained in Article 3 of Government Regulation of the Republic of Indonesia No. 21 of 2010, namely "Every crew member is obliged to prevent and overcome environmental pollution originating from his ship.

\section{Implementation of National and} International Environmental Laws against Marine Pollution Oil Spills in the Riau

\section{Islands Sea}

Internationally, on December 10, 1982, the international community succeeded in drafting the United Nations Convention on the Law of the Sea (United Nations Convention on the Law of the Sea), hereinafter referred to as the 1982 Convention on the Law of the Sea (KHL 1982). The 1982 Law of the Sea Convention regulates maritime issues as a whole, for example, regulating all forms of sea use and the utilization of the natural resources contained therein.

The provisions regulated by UNCLOS 1982 are the territorial sea maritime regime, exclusive economic zone (EEZ), continental shelf, archipelagic state, high seas, and so on. In the territorial sea, the coastal state has the sovereignty to determine the width of its territorial sea does not exceed 12 miles, and in this territorial sea, foreign ships have the right of innocent passage. UNCLOS 1982 also regulates the right of innocent passage.
Article 17 of UNCLOS 1982 gives rights to all countries, both coastal and non-coastal states, to enjoy the right of innocent passage through the territorial sea"

\section{Implementation of Environmental Pollution Law}

The development of environmental law cannot be separated from the worldwide movement to give greater attention to the environment, given the fact that the environment has become a problem that needs to be tackled together for the sake of survival in this world.

The preservation of natural resources must be guaranteed, among others, by maintaining the marine environment. In conditions that relate to the nature of the sea, as well as management systems in seeking existing natural resources. The growing awareness that is created will help coordinate the sea or meet the needs of the sea. This is a step towards realizing the preservation of the marine environment as well as the unlimited resources contained in the sea. In pursuing the sea, for example, fishing, excessive types of fish using tiger trawls are very dangerous and can cause extinction that cannot be felt in the short term.

Pollution of the marine environment is getting a lot of attention from the world today, whether it is nationally, regionally, or internationally due to its impact on environmental sustainability and the benefits of natural resources in the sea being disrupted both for the national interest of coastal countries and mankind as a whole.

Symptoms of pollution of the marine environment in the last decade have received a lot of attention from various parties. As seen in the discussions through seminars and symposiums held at the national, regional, and international levels, all of these concerns discussed and studied marine environmental issues, thereby sharpening understanding and raising awareness about marine environmental issues. 
This understanding and awareness generally imply that the problem of marine environmental pollution poses a threat to the life of both human, animal (fauna), and plant (flora) life. These three types of life that fill the environment or "biosphere" above the globe are threatened for their survival and sustainability because they are exposed to toxins that cause destruction. Therefore, the currents and winds of polluted seawater are spread everywhere evenly and affect the marine environment.

Constraint Factors in the Implementation of Marine Pollution Handling by Tankers in Riau Archipelago Waters, Especially in the Riau Islands Environmental Service. as follows:

Some of the constraining factors are

(1) Each state must have laws and regulations in place to ensure prompt and adequate compensation for losses caused by pollution of the marine environment by individuals or legal entities under its jurisdiction. In general, the status of responsibility is known by two characteristics, namely liability based on fault, and direct and immediate responsibility (strict liability). Therefore, each country must cooperate in implementing international law that regulates the responsibility and obligation of compensation for losses due to pollution of the marine environment and also the payment procedures such as whether there is mandatory insurance or compensation funds.

(2) The responsibility and obligation to compensate from the state, also known as state responsibility (state sovereignty), is a fundamental principle in international law, implying that if international obligations are violated, there will be a state responsibility. Violation of these international obligations is like not implementing the provisions contained in the 1982 Law of the Sea Convention, which is already binding on the country. The State's responsibility and obligation to provide compensation often occurs in cases of marine pollution, such as in the cases of Torrey Canyon 2967, Showa Maru 1975, Amoco Cadiz 1978. Exxon Valdez, 1989. In international law, no agreement expressly regulates state responsibilities.

(3) It should be noted that as far as the regulation of marine pollution by oil is concerned, the International Maritime Organization has played a very important role by having produced various international agreements on it. It can be said that the IMO is a leading organization in producing various regulations on marine pollution, especially those caused by oil.

(4) The 1982 Law of the Sea Convention (UNCLOS) also contains rules regarding the responsibilities and obligations of compensation concerning the protection and preservation of the marine environment. Article 235 of the Convention affirms that every state is responsible for carrying out international obligations regarding the protection and preservation of the marine environment so that all states must bear the obligation of compensation in accordance with international law, among others, if pollution is caused by activities under their jurisdiction or control, extending beyond those parts of the sea over which the state exercises sovereign rights.

\section{Efforts Made in the Implementation of Handling Marine Pollution by Tankers in Riau Archipelago Waters, Especially in the Riau Islands Environmental Service}

Environmental protection and management efforts are systematic and integrated efforts carried out to preserve environmental functions and prevent environmental pollution and/or damage which include planning, utilization, control, maintenance, supervision, and law enforcement so that it becomes an effort that can be done through (a) Article 6 of the Law on Environmental Protection and 
Management (UUPPLH) states that "everyone is obliged to maintain the preservation of environmental functions and to prevent, overcome pollution and environmental destruction." Thus, in terms of protecting and maintaining the environment, it is the obligation of every citizen of the state, meaning of environmental sustainability itself includes the preservation of the aquatic or marine environment, both national seas, and international seas. (b) Efforts to prevent and minimize pollution that occurs in the marine area caused by ships have various causes, in general, none other than the transportation of fuel oil, offshore oil drilling, oil refining, and the use of fuel oil products. Marine pollution is defined as the presence of dirt or waste from the activities of living things that enter the marine area. Other sources of marine pollution, apart from those described above, are the remnants of war munitions, ship discharges, and processes, industrial discharges into the sea, oil drilling processes at sea, waste disposal from land transportation through rivers, sea transportation emissions, and pesticide discharges from agriculture. However, the main source of marine pollution comes from oil spills, both from onboard processes, offshore drilling, and due to ship accidents. Pollution from oil spills in the sea is a source of marine pollution that has always been the focus of attention from the wider community because the consequences will be felt very quickly by the community around the coast and very significantly damage the living creatures around the coast. (c) Efforts to protect the marine environment and natural resources. These natural resources are found in the territory of Indonesia. Thus, this law places great importance on the protection of pollution that occurs in the Indonesian environment as a whole in various places, both on land and at sea. The importance of protecting the Indonesian marine environment includes the condition of the Indonesian marine environment, regulation of the marine environment, including the existence of international rights over Indonesian waters, and law enforcement efforts in cases of marine environmental pollution.

\section{RESEARCH METHODS}

The specification of the research applied is to use research with a combined writing method, namely the Juridical Normative and Empirical Normative legal research methods, which are basically a combination of normative legal approaches with the addition of various empirical elements. Normative and empirical research methods regarding the implementation of normative legal provisions (laws) in action on every particular legal event that occurs in society are combined.

This research refers to the legal norms contained in the laws and regulations that apply as a normative footing which starts from a general premise and then ends at a specific conclusion. This is intended to find new truths (a thesis) and basic truths (theoretical), which try to explain how to deal with marine pollution by tankers in Indonesian waters. This research was conducted in the area of the Riau Islands Environmental Service. In the opinion of the researcher, the consideration of choosing the research location is appropriate and in line with several research variables. Data collection is an attempt to collect materials related to research, which can be in the form of data, facts, symptoms, and information that are valid (actually), reliable (trustworthy), and objective (according to reality).

In this study, the data collection techniques used, namely: (a) depth interview using interview guidelines, is a conversation with a specific purpose. This conversation was carried out by two parties, namely the interviewer (who asked the question) and the interviewee (who provided the answer to the question). (b) Library research, supplemented by normative legal research using secondary data sources.

At the data analysis stage, processing of the data that has been 
collected, researched, and determined from the results of the research, the data is selected and compiled systematically so that it can be used as a reference in conducting the analysis. Furthermore, the authors compiled the results of research in a study that was in accordance with the subject matter, then processed, analyzed qualitatively, and presented descriptively, namely research that is expected to provide an overview of the Juridical Analysis of Marine Pollution by Tankers in the Riau Archipelago Waters (Research Study of the Archipelago Environmental Service). Riau). The data processing method used in this study is a qualitative analysis method, namely the data obtained is arranged systematically and then analyzed qualitatively in order to obtain clarity about the problems to be discussed.

Qualitative data analysis is a research method that produces descriptive data analysis, which is stated by the respondent in writing or verbally, and his real behavior is researched and studied in its entirety. The definition of analysis here is intended as an explanation and interpretation logically and systematically. Systematic logic shows how to think deductively and follow the rules in writing scientific research reports.

\section{DISCUSSION \& CONCLUSION}

Legal Regulation of Marine Pollution by Tanker Ships in the Riau Archipelago Waters. Regarding national legal rules, the national legal rules in Article 1 paragraph (3) of Law No. 4 of 1960 concerning Indonesian Waters state that Indonesia's inland waters are "All waters located on the inside as referred to in paragraph 2". Article 3 paragraph (4) of Law no. 6 of 1966 concerning Indonesian Waters, it is stated that "Indonesian Inland Waters are all waters located on the land side of the low water line of the Indonesian coasts, including all parts of the waters located on the land side of the closing line as referred to in Article 7".
Implementation of Marine Pollution Handling by Tanker Ships in Riau Archipelago Waters. Marine is a term that relates to all activities in the sea which include issues of sovereignty and authority of a country, exploration and exploitation of natural resources, both living and non-living on the surface, seabed and air space above it, and protection of the marine environment. In other words, the marine regulates matters related to the function of the sea as the largest provider of natural resources. Meanwhile, maritime refers more to navigation, trade (sea-borne trade), port affairs, and all kinds of activities related to maritime services. In other words, maritime includes matters related to the function of the sea as a means of transportation for the creation of trade by sea, especially international trade. The maritime environmental protection regulations that are emphasized are maritime law or commonly known as Maritime Law, which regulates the legal consequences of using the sea as a means of transportation, including such things as collision, salvage, towage, pilotage, and marine insurance. Thus, maritime law is more directed to private rules so that disputes arising from the implementation of maritime law will be resolved privately by the disputing parties, not necessarily involving the state.

The factors that become obstacles and the efforts made in handling marine pollution by tankers in the waters of the Riau Archipelago, especially in the Riau Islands Environmental Service. The factors that arise are the fact that each country must have laws and regulations regarding immediate and adequate compensation for losses caused by pollution of the marine environment by persons or legal entities within its jurisdiction. In general, the status of responsibility is known by two characteristics, namely liability based on fault, and direct and immediate responsibility (strict liability). Therefore, each country must cooperate in implementing international law that regulates the responsibility and obligation of 
compensation for losses due to pollution of the marine environment and also the payment procedures such as whether there is mandatory insurance or compensation funds. The responsibility and obligation for compensation from the state or called state sovereignty is a fundamental principle in international law so that if there is a violation of international obligations, the state will be responsible. Violation of these international obligations is like not implementing the provisions contained in the 1982 Law of the Sea Convention, which is already binding on the country. The State's responsibility and obligation to provide compensation often occurs in cases of marine pollution, such as in the cases of Torrey Canyon 2967, Showa Maru 1975, Amoco Cadiz 1978. Exxon Valdez, 1989. Maz Plant 2001, Prestige 2007, but there is no agreement that explicitly specifically regulates State responsibilities in international law. It should be noted that as far as the regulation of marine pollution by oil is concerned, the International Maritime Organization has played a very important role by having produced various international agreements on it. It can be said that the IMO is a leading organization in producing various regulations on marine pollution, especially those caused by oil.

\section{Suggestions}

In the understanding that must be taken into consideration, that it is very necessary to have clear legal arrangements in the implementation of handling marine pollution that occurs as a result of oil spills by tankers. This also includes oil spills that are intentionally carried out by small ships, because this always happens as a result of not all understanding the law and realizing the existence of a law so that aspects of lack of knowledge of legal arrangements often occur. Here, the role of government and institutions is a major factor in solving problems in the field.

In terms of implementation in handling marine pollution that occurred due to oil spills carried out by tankers in the
Riau Islands and even in Indonesian seas, this often resulted in violent turmoil between field officers and the applicant community, due to their selfishness and lack of understanding of the procedures that triggered it, the need for guidance as detailed as possible both in the form of directives and in the form of an appeal.

The existence of factors that become obstacles in the implementation of handling marine pollution problems that occur due to tanker oil spills is based on a dispute between misunderstandings about the applicable procedures, so that it often triggers the success factors of a program. In this case, the ministry of transportation must consider hard in order to be wiser in issuing ministerial regulations that are truly balanced from the aspect of needs that do not cause harm to one party.

\section{Acknowledgement: None}

\section{Conflict of Interest: None}

\section{Source of Funding: None}

\section{REFERENCES}

1. Abdulkadir, M. (2004). Hukum dan penelitian hukum.

2. Abdulkadir, M. (2010). Hukum Perusahaan Indonesia. Bandung: PT. Citra Aditya Bakti.

3. Adiwijoyo, S., \& Kartini. (2005). Konsolidasi wawasan maritim Indonesia. Pusat Kajian Informasi (Pakar).

4. Arifin, S. (2015). Aspek hukum perlindungan dan pengelolaan lingkungan hidup. Medan Area University Press.

5. Arifin, S., Munawir, Z., \& Syaputra, M. Y. A. (2015). Pengantar Hukum Indonesia. Citapustaka Media.

6. Aspan, H., Indrawan, M. I., \& Wahyuni, E. S. The authority of active partners and passive partners in the company type of commanditaire vennootschap.

7. Asshiddiqie, J., Indonesia, P. P. H. T. N., \& Reformasi, P. (2011). Perihal UndangUndang, Cetakan Kedua, Jakarta: PT. RajaGrafindo Persada.

8. Busroh, A. D., \& Busro, H. A. B. (1983). Asas-asas hukum tata Negara. Ghalia Indonesia. 
9. Chandra Motik, S. H. (2021). Serba Serbi Konsultasi Hukum Maritim. IND-HILLCO.

10. Darmiwati2021, D. (2021). Tanggung Gugat Terhadap Kerugian Yang Diterbitkan oleh Anak di Sekolah Berdasarkan Pasal 1367 KUHPerdata. Jurnal Hukum Das Sollen, 5(1).

11. Deni, L., Rumengan, J., \& Fadlan, F. (2020).Juridical analysis of the police role in the resolution of the mild theft problem through the mediation of penal: A research study in the Sagulung Police. IJARIIE 6 (4), 197-207

12. Dimyati, K., \& Wardiono, K. (2004). Metodologi Penelitian Hukum.

13. Fadlan, F. (2019). Government Policy Regarding Building Permits in Indonesia. International Journal of Research Culture Society 3 (11), 150-154.

14. Fadlan, F. (2019). Perkembangan Kebijakan Daerah Sebagai Paradigma Dasar Untuk Penentuan Kebijakan Mengelola Potensi Keberagaman. Soumatera Law Review 2 (1), 2620-5904

15. Fadlan, F. (2020).Debtor's Guarantee in Providing the Convenience of Credit Agreement. International Journal of Research Culture Society 6 (1), 159-162.

16. Friedmann, W. (1990). Teori dan Filsafat Hukum. Telaah Kritis atas Teori-teori Hukum, jilid II, Terjemahan Mohammad Arifin dari Legal Thoery,(Jakarta: Raja Rgafindo Persada, 1996).

17. Friedmann, W., Saqib, S., \& Budiman, A. N. (1919). Teori dan Filsafat Hukum II: Idealisme Filosofis dan Problema Keadilan.

18. Hart, H. L. A. (1961). The Concept of Law, the English Language Book Society and Oxford University Press.

19. Hartono. (2010). Penyidikan \& penegakan hukum pidana melalui pendekatan hukum progresif. Sinar Grafika.

20. Idham (2004). Konsolidasi tanah Perkotaan Guna Meneguhkan Kedaulatan Rakyat. Alumni Bandung.

21. Idham (2014). Konsolodasi Tanah Perkotaan dalam Prespektif Otonomi Daerah, PT. Alumni, Bandung.

22. Idham, H. (2014). Konsolidasi Tanah Perkotaan Dalam Perspektif Otonomi Daerah Guna Meneguhkan Kedaulatan Rakyat dan Negara Berkesejahteraan-Edisi Kedua.
23. Idham, I., Juliandi, A., Fadlan, F., \& I. M. (2018). Political Paradigm of Complete Systematic Land Registration Law to Actualize Economic Growth Compliance in Batam City, Indonesia. Journal of Arts \& Humanities, 7(10), 13-29.

24. Idham. (2005). Konsolidasi tanah perkotaan dalam perspektif otonomi daerah. Alumni. Bandung.

25. Ikhsan, P.A., Fadlan, F., \& Idham, I. (2021). Analisis Yuridis Proses Penyidikan Terhadap Tindak Pidana Penganiayaan Yang Dilakukan Oleh Anak (Studi Penelitian Di Polsek Nongsa). Zona Keadilan: Program Studi Ilmu Hukum (S1) Universitas Batam 10 (2), 1-17

26. Kandou, S. (2016). Tinjauan Yuridis Jaminan Hipotik Kapal Laut Dan Akibat Hukumnya. Lex Crimen, 5(4).

27. Leden, M. (2005). Asas-Teori-Praktik Hukum Pidana.

28. Lubis, M. S. (1994). Filsafat Ilmu dan Penelitian. Bandung: Mandar Maju.

29. Magee, B. (1998). The story of philosophy.

30. Martono, K., \& Tjahjono, E. B. (2011). Transportasi di perairan berdasarkan Undang-Undang nomor 17 tahun 2008. Rajawali Pers.

31. Mediheryanto, M., Rumengan. J., \& Fadlan, F., (2020).Analysis of Juridical Legal Protection of Women Reproductive Health in Family Planning: A Research Study in Batam City. Scholars International Journal of Law, Crime and Justice 7 (7), 97-107

32. Mertokusumo, S. (2007). Mengenal Hukum; Suatu Pengantar.

33. Moleong, L. J. (2021). Metodologi penelitian kualitatif. PT Remaja Rosdakarya.

34. Muhammad, R. (2015). Pengaturan dan Urgensi Whistle Blower dan Justice Collaborator dalam Sistem Peradilan Pidana. Jurnal Hukum Ius Quia Iustum, 22(2), 203-222.

35. Nasrudin, N., Washliati, L., \& Fadlan, F. (2021). Analisis Yuridis Perlindungan Hukum Terhadap Hak Milik Diatas Tanah Hak Pengelolaan Lahan Untuk Mewujudkan Kepastian Hukum (Studi Penelitian Kantor Pertanahan Kota Batam). Zona Hukum: Jurnal Hukum, 14(2), 37-55.

36. Prastyo, A., Fadlan, F., \& Fadjriani, L.(2021). Analisis Yuridis Terhadap Keberangkatan Kapal Penumpang Tanpa Adanya Surat Persetujuan Berlayar (Studi 
Danny Priabudi et.al. Juridical analysis of marine pollution by tankers in riau archipelago waters: a case study at the environmental service, Riau Islands.

Penelitian Kantor Kesyahbandaran Dan Otoritas Pelabuhan Khusus Batam). Zona Keadilan: Program Studi Ilmu Hukum (S1) Universitas Batam 10 (3), 1-15

37. Prodjodikoro, W. (1976). Hukum laut bagi Indonesia.

38. Purba, H. (2005). Hukum pengangkutan di laut: perspektif teori dan praktek. Pustaka Bangsa Press.

39. Purnomo, D. H. (2004). Pengamanan Laut RI Bagian Barat. Jurnal Hukum Internasional.

40. Purwosutjipto, H. M. N., \& Indonesia, P. P. H. D. (2000). Hukum Pelayaran Laut Dan Perairan Darat. Djambatan, Jakarta.

41. Rasjidi, H. L. (2004). Dasar-dasar filasafat dan teori hukum. Penerbit PT Citra Aditya Bakti.

42. Rhiti, H. (2011). Filsafat Hukum Edisi Lengkap (dari klasik sampai postmodernisme). Universitas Atma Jaya Yogyakarta, Yogyakarta.

43. Salim, H. S. (2016). Perkembangan hukum jaminan di Indonesia. Ar-Ruzz Media,.

44. Salman, O. HR Dan Anthon F. Susanto, 2011. Teori Hukum Mengingat, Mengumpulkan dan Membuka Kembali.

45. Salman, O., \& Susanto, A. F. (2004). Teori Hukum. Refika Aditama, Bandung.

46. Saputra, N., Rumengan, J., Idham, I., \& Fadlan, F. (2020).Juridical Analysis of the Code of Conduct Violations in Perspective to Determine the Establishment of the Notary Position: A Research Related to the Notary Public in Batam City International Journal of Research Publication And Reviews 1 (3), 8-12.

47. Sari, U. P. (2015). Arikunto, Suharsimi. 2010. Prosedur Penelitian: Suatu Pendekatan Praktik. PT. Rineka Cipta. Mahsun. 2011. Metode Penelitian Bahasa: Tahap Strategi, Metode, dan Tekniknya. Jakarta: PT Raja Grafindo Persada. Najid, Moh. 2003. Mengenal Apresiasi Prosa Fiksi. Surabaya: University (Doctoral dissertation, Universitas Mataram).

48. Soekanto, S., \& Mamudji, S. (2001). Penelitian hukum normatif: Suatu tinjauan singkat.

49. Soekanto, S., \& Mamudji, S. (2001). Penelitian hukum normatif: Suatu tinjauan singkat.

50. Soemitro, R. H. (1990). Metodologi penelitian hukum dan jurimetri. Ghalia Indonesia, Jakarta, 167.
51. Soimin, \& Mashuriyanto. (2013). Mahkamah Konstitusi dalam sistem ketatanegaraan Indonesia. UII Press.

52. Starke, J. G. (2003). Pengantar Hukum Internasional 1.

53. Stevanus, J., Rumengan, J., Idham, I., \& Fadlan. (2020).Juridical analysis of the auction of fiduciary collaterals on unregistered fiduciary deed: A research study in the Kemenkumham Regional Office, Tanjung Pinang, Indonesia

54. Subagyo, J. (2005). Hukum Laut Indonesia. Rineka CiPT.a, Jakarta,

55. Sudikno, M. (2011). Teori Hukum. Universitas Atmajaya, Yogyakarta.

56. Suparni, N., \& Hamzah, A. (2003). KUHD (Kitab Undang-Undang Hukum Dagang) dan Kepailitan.

57. Susetyorini, P. (2017). Hak Berdaulat Negara Kesatuan Republik Indonesia Di Kepulauan Natuna (Studi Khusus Indonesia Terhadap Klaim Peta Nine-Dashed Line China Di Kepulauan Natuna). Diponegoro Law Review, 6(2), 1-13.

58. Syahrin, A., \& Hadyanto, S. (2009). Beberapa Masalah Hukum. Sofmedia.

59. Syawal, S., Rumengan, J., Idham, I., \& Fadlan, F. (2020). Juridical Analysis of the Responsibilities of Directors in the Perspective of Creating Good Corporate Governance: A Research Study in Pt Putra Raflesia, Batam- Indonesia. International Journal of Research and Review 7 (6), 430439.

60. Tanya, B. L., Simanjuntak, Y. N., \& Hage, M. Y. (2010). Teori Hukum Strategi Tertib Manusia Lintas Ruang dan Generasi. Yogyakarta: Genta Publishing.

61. Utami, H. P., Rumengan, J., Prasetiasari, C., \& Idham, I. (2021). Analisis Yuridis Pemenuhan Hak Anak Didik Pemasyarakatan Untuk Mendapatkan Pembinaan (Studi Penelitian Lembaga Pembinaan Khusus Anak Kelas II Batam). Zona Hukum: Jurnal Hukum, 14(2), 56-87.

62. Wisok, Y. P. (2009). Etika mengalami krisis, membangun pendirian.

63. Yulindo, R., Jihad, K., \& Fadlan, F. (2021). Analisis Yuridis Tindak Pidana Khusus Pencucian Uang Yang Berasal Dari Tindak Pidana Narkotika (Studi Penelitian Putusan Pengadilan). Zona Keadilan: Program Studi Ilmu Hukum (S1) Universitas Batam 10 (2), 75-93. 
Danny Priabudi et.al. Juridical analysis of marine pollution by tankers in riau archipelago waters: a case study at the environmental service, Riau Islands.

64. Yusril, Y., Rumengan, J., Idham, I., \& Fadlan, F. (2020). Juridical Analysis of the Transfer of Ownership of Objects Which are Still the Responsibility of Other Debtors for Legal Certainty; A Research Study at PT.BPR LSE Manggala. International Journal of Research and Review 7 (7), 97 107.
How to cite this article: Priabudi D; Washliati L; Idham. Juridical analysis of marine pollution by tankers in riau archipelago waters: a case study at the environmental service, Riau Islands. International Journal of Research and Review. 2021; 8(10): 497-510. DOI: https://doi.org/10. 52403/ijrr.20211064 